\title{
Evaluation of electrical conductivity and density of 8 mol\% yttria-stabilized zirconia produced by Spark Plasma Sintering
}

P. T. B. Polla

M. I. Valentini'

N. V. Junior ${ }^{1}$
M. A. C. Berton'

L. da Conceição'

\section{Abstract}

In this work, $8 \mathrm{~mol} \%$ yttria-stabilized zirconia ( $8 \%$ YSZ) containing micro or nanoparticles were manufactured by Spark Plasma Sintering technique, in order to improve sample densification and control grain growth. The electrical conductivity of dense $8 \%$ YSZ pellets sintered was investigated by electrochemical impedance spectroscopy (EIS). Preliminary results showed for samples produced from both micro and nanoparticle sintered at $1000{ }^{\circ} \mathrm{C}$ for $5 \mathrm{~min}$, the relative density is approximately $98 \%$, while for the others samples sintered at $1200{ }^{\circ} \mathrm{C}$ the density is above $99 \%$. These densities are higher in comparison to the same composite sintered by conventional method. The electrical measurements were carried out at $500{ }^{\circ} \mathrm{C}$ in air and the best results were obtained for samples with nano particle size in comparison with micro granulometry. The SPS process allows using lower temperatures and shorter times to produce materials with high density and controlled grain growth.

Keywords: 8\% YSZ, Spark Plasma Sintering, relative density, ionic conductor, solid electrolyte.

\section{Introduction}

Solid Oxide Fuel Cell (SOFC) is a device, which converts chemical energy to electrical energy through chemical reactions [1]. In short, this device resembles a

1 SENAI Institute of Innovation in Electrochemistry, Curitiba, Paraná, Brazil. 
battery which the electrodes are not consumed during the discharge, simply acting as places for the reactions between the fuel and the oxidant [2-3]. SOFC is an efficient and environmental designed technology, which presents low toxic gases emission in comparison with other combustion processes, as combustion engines [1-4]. SOFCs may be differentiated by the operation temperature, ranging from $500{ }^{\circ} \mathrm{C}$ to $1000{ }^{\circ} \mathrm{C}$. The transport of oxygen ions through the electrolyte is quite low on temperatures under $500{ }^{\circ} \mathrm{C}$, what leads that better efficiency and power are observed at high temperatures for SOFCs [1-2,5].

Among the most used materials for electrolytes on SOFCs which operates at high temperatures (e.g. $800{ }^{\circ} \mathrm{C}-1000{ }^{\circ} \mathrm{C}$ ), the Yttria Stabilized Zirconia (YSZ) has some advantages [6-7]. Currently, the sold $8 \%$ YSZ electrolytes $\left(\mathrm{ZrO}_{2}: 8 \mathrm{~mol} \% \mathrm{Y}_{2} \mathrm{O}_{3}\right)$ have particle size on the range from $5 \mathrm{~nm}$ to $7 \mu \mathrm{m}$. Besides the ionic conductivity, the yttria stabilized zirconia has good resistance to corrosion, low thermic conductivity, high hardness and chemical stability on high temperatures. These properties assist to explain why yttria stabilized zirconia is one of most studied materials for fuel cells application. However, there are some challenges to overcome, as electrode polarization and ohmic loss on electrolyte [8]. Although, the starting material's microstructure is strongly influenced by samples preparation conditions, as granulometry and sintering temperature.

One of biggest challenges present on sintered solid electrolyte production for SOFC is the difficulty on reaching a high apparent density through a sintering process which can controls the grain's growth and contour, being economically viable. Porosity results on electrolyte ionic conductivity decreasing and when the communicant porosity occurs there is SOFC efficiency loss due to non-ionized oxygen migration to the anode. Sintering is one of most important steps on $8 \%$ YSZ electrolytes processing. This requirement imposes to $8 \%$ YSZ electrolytes a minimum relative density of $93 \%$, but the commercial $8 \%$ YSZ powder can reach a high density after conventional sintering only at temperatures above $1350{ }^{\circ} \mathrm{C}$, associated to long times of sintering [9].

Sintering is a thermodynamic process on which a particle system gets a solid structure, through the decreasing on specific superficial area, leading the system (in most of cases) to the retraction and consequently to the densification [10-11]. During the sintering, the powder particle's superficial energy decreases according to the mass transport's mechanisms variation. These mechanisms are usually thermally activated, and are predominant in specific temperature ranges. Among the numerous sintering employed techniques we may cite: Flash Sintering [12], Two Step Sintering [13] and Spark Plasma Sin- 
tering (SPS) [14-15]. The innovative technique of SPS sintering is quite promising for conductive ceramic production.

There are different variations on sintering techniques for ceramic-powder through the application of current and compaction pressure, among them the most innovative is the SPS. However, on literature the terms "Pulsed Electric Current Sintering" (PECS) and "Field Assisted Sintering Technique" (FAST) are used in order to avoid the employ of word "plasma", because its existence on the process is still discussed. The SPS sintering process allows the use of lower temperatures and time (few minutes), in comparison with the conventional sintering, producing dense materials with low grain growth [1517]. This process uses pulsed continuous current simultaneously to a uniaxial compaction pressure to consolidate the powder. The increasing on uniaxial compaction pressure allows getting higher densification values keeping the same temperature and sintering time landing. The compaction pressure creates change on particle rearrangement and fragmentation of present clusters, especially in nanometric powder.

Punctures and dense graphite matrix are used on the process due to their excellent electric conductivity and thermic resistance. The control of atmosphere during the sintering is another important characteristic of SPS. The high vacuum is usually employed to the powder consolidation, but it is also possible to use inert gases, as helium and argon. Figure 1 shows the operation scheme of a SPS equipment installed on Senai Innovation Institute of Electrochemistry (ISI-EQ), from Curitiba - PR, Brazil.

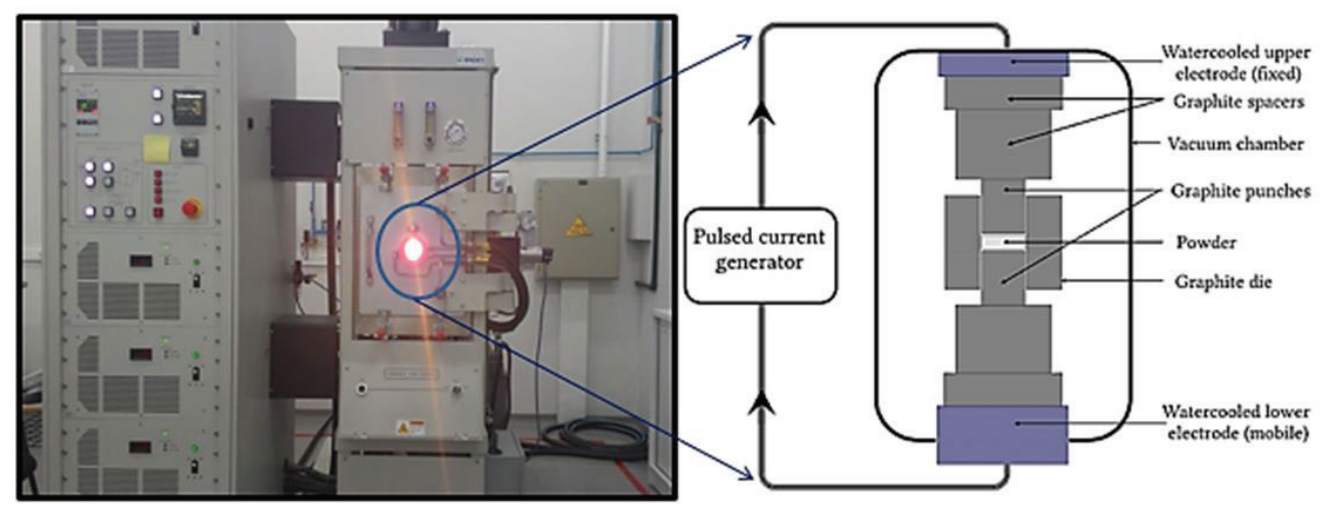

Figure 1 Photograph of SPS 10-4 GT Advanced Technologies equipment, installed on ISI-EQ and, on the detail, the basic scheme of a SPS oven [16]. 
The sintering of YSZ composed materials using the SPS technique has been accomplished for different studies of obtained ceramic, as densification [18], ionic conductivity [19-20], microstructure [21] and comparison with conventional sintering technique studies [19,22].

The objective of this work is show preliminary results successfully obtained on $8 \%$ YSZ electrolyte using SPS sintering. Evaluations on the morphology, ceramic microstructure (with nano and micro sized granulometry) and on the increasing of relative density were done. The electric properties of sintered samples were also evaluated by Electrochemical Impedance Spectroscopy.

\section{Materials and methods}

\subsection{Samples preparation and sintering}

For samples preparation, two different granulometry of commercial $8 \%$ YSZ powder (from Fuel Cell Materials - EUA) was chosen. The commercial micro sized powder was produced for Tape-Casting, its particle average size was $7 \mu \mathrm{m}$ and the superficial area was $6.1 \mathrm{~m}^{2} / \mathrm{g}$. The nano sized powder had particle average size of $5 \mathrm{~nm}$ and the superficial area was $153.4 \mathrm{~m}^{2} / \mathrm{g}$. Both powder had fluorite stabilized kind cubic structure.

The sintering process was accomplished in a SPS oven, produced by GT Advanced Technologies. For all samples it was used $0.52 \mathrm{~g}$ of YSZ powder in a graphite matrix with outside diameter of $30 \mathrm{~mm}$, height of $40 \mathrm{~mm}$ and punctures diameter of $10 \mathrm{~mm}$. The employed amount of powder allows to obtain a disc with $2 \mathrm{~mm}$ of thickness. Previously to each sintering thermic cycle, it was reached a pressure under $8.10^{-3} \mathrm{~Pa}$ in the chamber, with the help of a vacuum pump. For samples compaction a pressure of $50 \mathrm{MPa}$ was applied, in a heating rate of 100 ${ }^{\circ} \mathrm{C} . \mathrm{min}^{-1}$ to the sintering temperature landing and kept for 5 minutes, then the samples were cooled down in a rate of $100^{\circ} \mathrm{C} \cdot \mathrm{min}^{-1}$. The samples were produced at the temperatures of $1000{ }^{\circ} \mathrm{C} \mathrm{e} 1200^{\circ} \mathrm{C}$. For chamber's temperature monitoring it was used an infrared pyrometer, which register the temperature of outside wall on the mold. Figure 2 shows, as an example, a typical graph of parameters given by the equipment. 


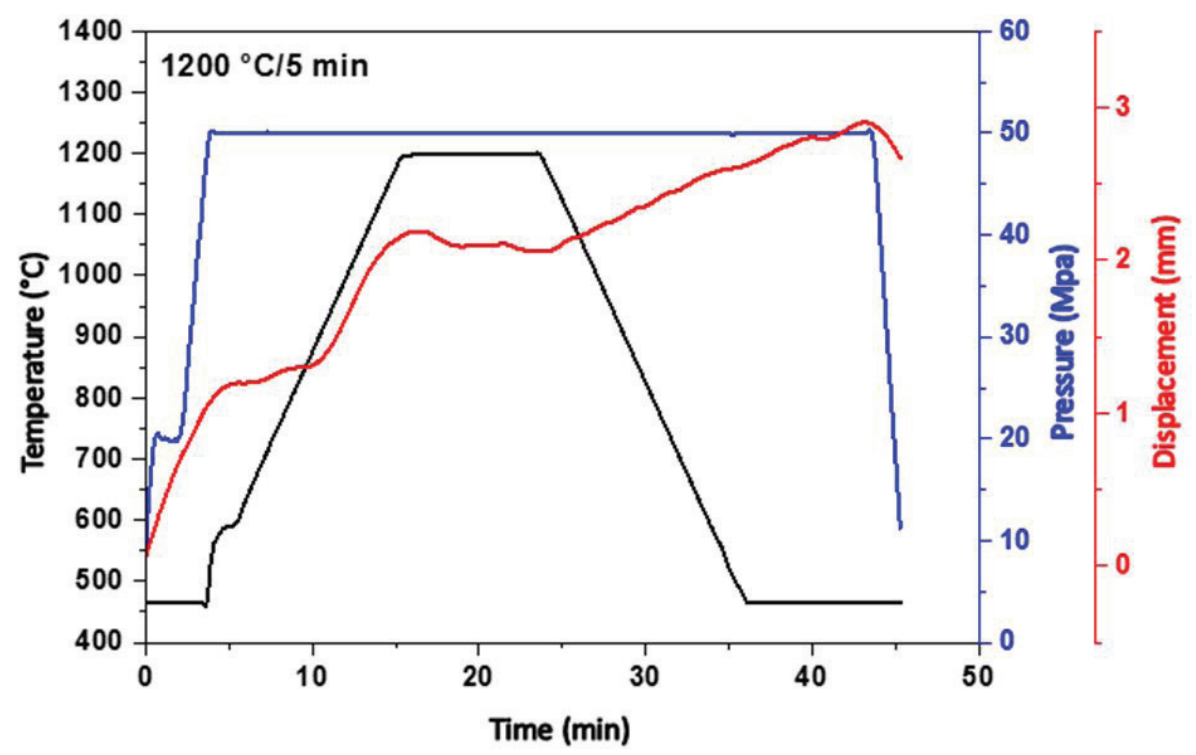

Figure 2 Profile of parameters registered by SPS equipment during the sintering at $1200^{\circ} \mathrm{C}$ for $5 \mathrm{~min}$.

After sintering, the samples were submitted to a thermic treatment to remove superficial residual carbon, which remains from the contamination by the graphite mold, in muffle oven from Jung (Brazil) brand. The thermic treatment was done at $1000{ }^{\circ} \mathrm{C}$, in a rate of $15^{\circ} \mathrm{C} \cdot \mathrm{min}^{-1}$ with 2 hours landing and then cooling in the oven at $15^{\circ} \mathrm{C} \cdot \mathrm{min}^{-1}$ in air atmosphere.

\subsection{Density measurements}

The apparent density of sintered samples was determined by the water immersion method, using the Archimedes' principle, and compared with the theoretical density of YSZ $\left(5.901 \mathrm{~g} / \mathrm{cm}^{3}\right)$. For this procedure a container containing distilled water and a Mettler Toledo model XS204 balance were used. The samples were put in a in the container containing water at $90^{\circ} \mathrm{C}$ during 2 hours in order to achieve better filling of accessible pores. The apparent density of one material is defined by the relation between its weight and volume, usually expressed on grams per cubic centimeter $\left(\mathrm{g} / \mathrm{cm}^{3}\right)$.

\subsection{Morphological and microstructural characterization}

The polished surfaces of the sintered pellets were inspected by FEG-Scanning Electron Microscope (FEI Inspect F50). The sintered samples were sec- 
tioned in cutter IsoMet (Buehler) and the polishing was done sequentially with silicon carbide sandpapers and 6,3 and $1 \mu \mathrm{m}$ diamond pastes, with further ultrasonic cleaning with ethanol. The polished specimens were thermally etched at $100{ }^{\circ} \mathrm{C}$ below the sintering temperature, in air flow, for $60 \mathrm{~min}$ to reveal the surface grain boundaries.

\subsection{Electrochemical impedance spectroscopy}

The electrical conductivity measurements of sintered materials were made using a frequency response analyzer of the from Solartron model SI-1260, connected to a measurement cell consisted by a alumina pipes and platinum wires system, similar to the previously one reported on literature [23]. For electric measurements, the YSZ samples were recovered on both faces with a silver dough produced by Tanaka Kikinzoku (Japan) and cured at $500{ }^{\circ} \mathrm{C}$ in air atmosphere. This procedure leads to better contact point with platinum wires and uniform current distribution. The electric measurements were accomplished at $500{ }^{\circ} \mathrm{C}$ in order to simulate a $\mathrm{SOFC}$ operation temperature, and using a frequency range from $5 \mathrm{~Hz}$ to $13 \mathrm{MHz}$, with perturbation signal amplitude of $300 \mathrm{mV}$. The obtained data were treated using the ZPlot/ZView (Scribner Associates Inc.) software, which provides simultaneously the Bode diagram (impedance module and phase angle versus frequency) and the Nyquist diagram (imaginary part of impedance - Z" versus real part of impedance $-Z^{\prime}$ ).

\section{Results and discussion}

The densification process is always a challenge on ceramic electrolytes production for SOFC application, and sintering is the most important process to achieve high densities with a desired microstructure. For the conventional sintering process, the increasing on sintering temperature is one of found ways to increase YSZ densification, however temperatures above $1400{ }^{\circ} \mathrm{C}$ are required to obtain sintered materials with relative density higher than 95\% [24]. On Table 1 are shown the conditions studied for SPS sintering and the relative densities of sintered samples. To calculate the relative density, the value of $5.901 \mathrm{~g} / \mathrm{cm}^{3}$ was adopted for theoretical density, as done on Rajeswari et.al work [19-20] on which the material had the same composition. It was possible to observe that for both chosen sintering temperatures, the samples showed high densification, with relative density upper than $98 \%$, being that for the samples sintered at $1200{ }^{\circ} \mathrm{C}$ the density was above than $99 \%$. 
Table 1 Values of Apparent density of 8\%YSZ samples sintered by SPS at different temperatures.

\begin{tabular}{|l|l|l|l|l|}
\hline \multirow{2}{*}{$\begin{array}{c}\text { TemperaturE } \\
\left({ }^{\circ} \mathbf{C}\right)\end{array}$} & \multirow{2}{*}{$\begin{array}{c}\text { Time } \\
(\mathbf{m i n})\end{array}$} & \multirow{2}{*}{$\begin{array}{c}\text { Pressure } \\
(\mathbf{M P a})\end{array}$} & \multicolumn{2}{|c|}{ Relative Density (\%) } \\
\cline { 4 - 5 } & & & Micro & Nano \\
\hline 1000 & 5 & 60 & 98.31 & 98.17 \\
\hline 1200 & & & 99.97 & 99.81 \\
\hline
\end{tabular}

Other way used and described on literature to increase $8 \%$ YSZ densification is the addition of $\mathrm{NiO}$ (in proportions of 40-60 wt.\%) [20]. Van Herle and Vasquez [25] observed fast densification of $8 \%$ YSZ with the addition of small amounts of $\mathrm{NiO}(1.5 \%$ in $\mathrm{mol})$. Recently, Zhang et al. [26] reported an improvement on $8 \%$ YSZ densification with $\mathrm{NiO}$ addition. However, all sintering processes in these cases were accomplished on the conventional method, which involves high temperatures and long time of sintering $(\sim 24 \mathrm{~h})$. On the other hand, the samples sintered by SPS on this work (independently of nano or micro granulometry) showed that with a fast heating and under applied pressure by SPS it was possible to reach high density values on lower temperatures in comparison with the conventional process.

In Figure 3 the scanning electron microscopy images of the $8 \%$ YSZ samples sintered at (a) $1000^{\circ} \mathrm{C}$ and (b) $1200^{\circ} \mathrm{C}$ for 5 min by SPS both starting from the powder with micrometric granulometry are presented. The image that for the sintered sample at $1000{ }^{\circ} \mathrm{C}$ with micro particles size presents porosity, while the sample sintered at $1200{ }^{\circ} \mathrm{C}$ densification increases with an average grain size of $550 \mathrm{~nm}$.

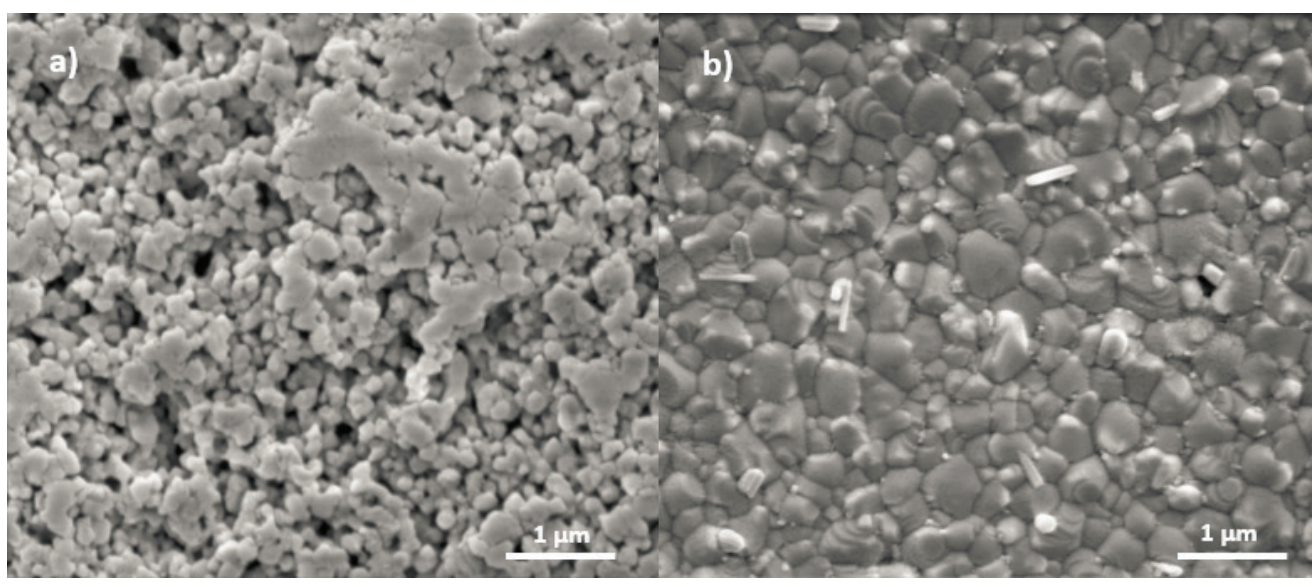

Figure 3 SEM images of the $8 \%$ YSZ samples sintered at (a) $1000{ }^{\circ} \mathrm{C}$ and (b) $1200^{\circ} \mathrm{C}$ for 5 minutes by SPS using powder with micrometric granulometry. 
Figure 4 shows the scanning electron microscopy images of the $8 \%$ YSZ nano particles samples sintered at $1200{ }^{\circ} \mathrm{C}$ for $5 \mathrm{~min}$ via SPS both starting from the powder with nanometric granulometry. For the sample sintered at $1200{ }^{\circ} \mathrm{C}$ with nano powder the densification increases significantly, with an average grain size of $100 \mathrm{~nm}$, this result already shows an evolution in the sintering process by SPS when the nano powder is used.

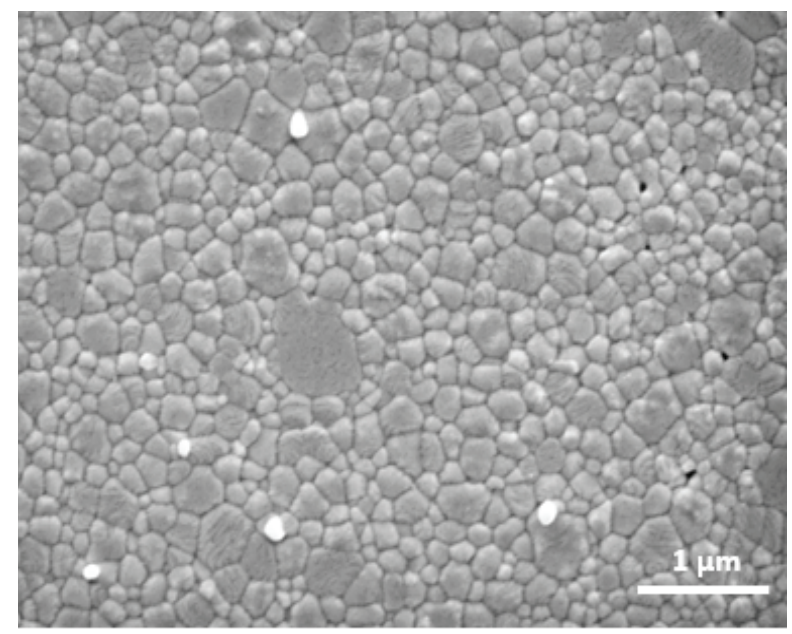

Figure 4 SEM images of the $8 \%$ YSZ samples sintered at $1200^{\circ} \mathrm{C}$ for 5 minutes via SPS using powder with nanometric granulometry.

On Figure 5 are shown the Nyquist diagrams obtained for the sintered sample at (A) $1000{ }^{\circ} \mathrm{C}$ micro and nano and (B) $1000^{\circ} \mathrm{C}$ and $1200{ }^{\circ} \mathrm{C}$ nano, for 5 minutes via SPS. The impedance diagram for $8 \% \mathrm{YSZ}$ phase with the samples sintered at $1000{ }^{\circ} \mathrm{C}$ with nano and micro powder (Figure 5 (A)), shows two characteristic contributions: (I) grain ionic conduction and (II) conduction on grain's contour. The conduction on grain occurs at high frequencies, being the first semicircle observed on diagram, while the polarization of grain's contour occurs at lower frequencies, corresponding to the second semicircle of diagram. The occurrence of grain's semicircle at high frequencies is due to the ionic and dipolar polarization while the one of grain's contour is related to polarization for special charge [27]. The first semicircle (high frequency region) of real axis $Z$ ' represents the polarization of grain and the second semicircle (low frequency regions) of $Z^{\prime}$ axis represents the grain's contour polarization. For the present work, both (grain conductivity and grain's contour conductivity) showed be dependent of the size of precursor particles used on sintered preparation. For the sample sintered with nano powder it was observed a significant decreasing on material's resistivity in comparison to the sample prepared from the micro sized powder in the same 
sintering conditions, because the size of grains formed after sintering are smaller, resulting in a bigger grain's contour area and, consequently, better conductivity by the grain's contour.

On Figure $5(\mathrm{~B})$ is represented the impedance diagram for the $8 \% \mathrm{YSZ}$ phase with the samples sintered under $1000{ }^{\circ} \mathrm{C}$ and $1200{ }^{\circ} \mathrm{C}$ using nano sized powder. It was possible to observe clearly for the sample sintered at $1200{ }^{\circ} \mathrm{C}$ both characteristic contributions: (I) ionic grain conduction and (II) grain's contour conduction. Is also evident that a significant decreasing on nano material resistivity, when the material is sintered at higher temperature. The significant improvement on nano sized material conductivity due to the increasing of temperature may be attributed to a better sinterability and higher density obtained, when sintered by SPS technique.
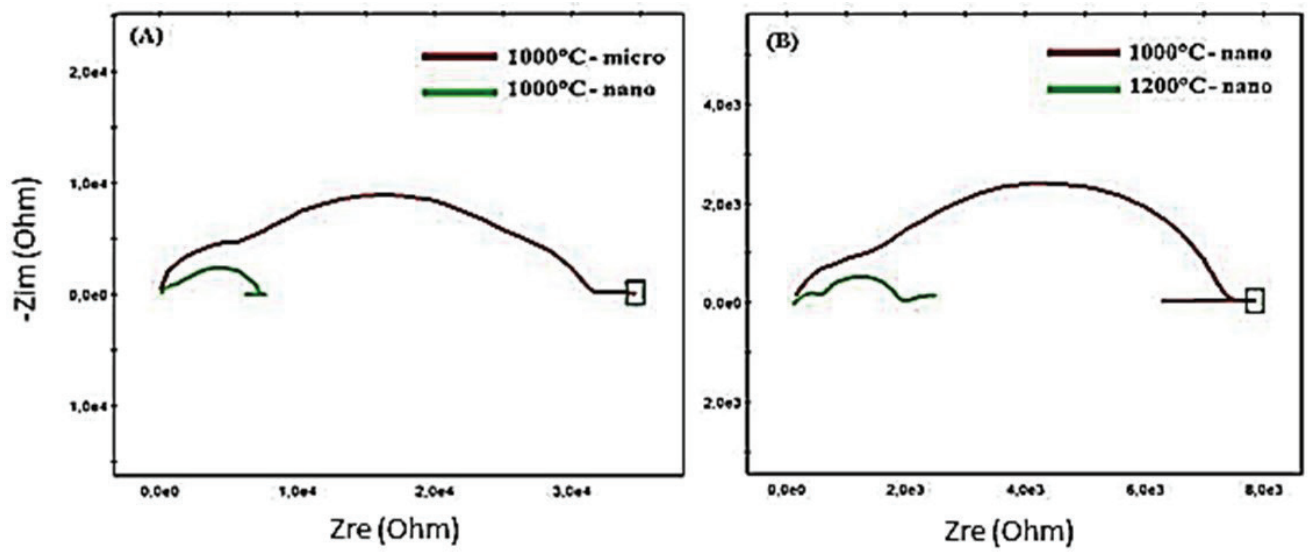

Figure 5 Impedance diagram obtained at $400^{\circ} \mathrm{C}$ for $8 \%$ YSZ sample (A) $1000^{\circ} \mathrm{C}$ micro and nano (B) $1000^{\circ} \mathrm{C}$ and $1200^{\circ} \mathrm{C}$ nano, sintered by SPS.

The grains growth in $8 \%$ YSZ electrolytes related to the electric behavior will be more explored on future employing the impedance spectroscopy technique, following the dependence of grains and grain's contour resistivity on the material's sinterability conditions. The increase on grains size may be determined with accuracy on impedance diagrams to evaluate its kinetics. Evaluations by Electrochemical Impedance Spectroscopy, after conductive ceramic sintering may contribute to establish the parameters employed in SPS sintering processes and mechanisms.

\section{Conclusion}

Ceramic materials based on yttria stabilized zirconia $8 \% \mathrm{YSZ}-\left(\mathrm{ZrO}_{2}: 8\right.$ mol\% $\mathrm{Y}_{2} \mathrm{O}_{3}$ ) with nano and micro granulometry from Fuel Cell Materials were sintered successfully by the Spark Plasma Sintering technique. After 5 
minutes of sintering at temperatures of $1000{ }^{\circ} \mathrm{C}$ and $1200{ }^{\circ} \mathrm{C}$ and pressure of $60 \mathrm{MPa}$, preliminary results showed that, independently of granulometry, ceramic sintered at $1000{ }^{\circ} \mathrm{C}$ had relative density of $98 \%$ approximately, while for the samples sintered at $1200{ }^{\circ} \mathrm{C}$ the densification was above $99 \%$. This density is higher than the relative densities obtained for the same material using the conventional sintering technique, employing a temperature above $1300{ }^{\circ} \mathrm{C}$ for 24 hours.

The electrical conductivity of dense $8 \%$ YSZ sintered discs was investigated by Electrochemical Impedance Spectroscopy. The impedance diagrams profiles showed two characteristic contributions: (I) grain ionic conduction and (II) grain's contour conduction. The electric conductivity agrees with the conductivities of $8 \%$ YSZ phase reported on literature. The electric impedance diagrams showed that the sample using nano powder presented lower resistivity than the sample using micro powder, both sintered at $1000{ }^{\circ} \mathrm{C}$, due to the size of grains formed after sintering, because smaller grains show bigger grain's contour area, what improves the conductivity of material. The impedance diagrams also demonstrated that samples sintered using nano powder had better result when the sintering temperature was increased to $1200^{\circ} \mathrm{C}$. The SPS sintering process allows the using of lower temperatures and shorter time relatively short, producing materials with high densification and it was possible to observe that it influences positively on the improvement on the ionic conductivity of materials.

\section{Acknowledgment}

The authors thank the Regional Directory of SENAI, National Directory of SENAI, CNPq and BNDES for financial support and to Prof. Reginaldo Muccillo from IPEN for the FEG-SEM analysis.

\section{References}

[1] A. B. Stambouli, E. Traversa, Solid oxide fuel cells (SOFCs): a review of an environmentally clean and efficient source of energy, Renewable and Sustainable Energy Reviews, 2002, vol. 6, n. 5, 433-455.

[2] D. Z. Florio, F. C. Fonseca, E. N. S. Muccillo, R. Muccillo, Materiais Cerâmicos para Células a Combustível, Cerâmica, 2004, vol. 50, n. 316, 275-290.

[3] L. Conceição, Catodos a Base de Manganita de Lantânio: Avaliação de metodologias de síntese e caracterização, 2011, 1 ed., São Paulo, Blucher. 
[4] A. Atkinson, S. Barnett, R. J. Gorte, J. T. S. Irvine, A. J. McEvoy, M. Mogensen, S. C. Singhal, J. Vohs, Advanced anodes for high-temperature fuel cells, Nature Mater, 2004, vol. 3, n.1, 17-27.

[5] M. E. Medeiros, R. S. Amado, L. F. B. Malta, F. M. S. Garrido, Pilhas a combustível de óxido sólido: materiais, componentes e configurações, Química Nova, 2007, vol. 30, n.1, 189-197.

[6] A. Weber, E. Ivers-Tiffée, Materials and Concepts for solid oxide fuel cells (SOFCs) in stationary and mobile applications, Journal of Power Sources, 2004, vol. 127, n.1-2, 273-283.

[7] M. Gaudon, E. Djurado, N. H. Menzler, Morphology and sintering behavior of yttria stabilized zirconia (8-YSZ) powders synthesized by spray pyrolysis, Ceramics International, 2004, vol. 30, n. 8, 2295-2303.

[8] J. Seydel, M. Becker, E. Ivers-Tiffée, H. Hahn, Granular nanocrystalline zirconia electrolyte layers deposited on porous SOFC cathode substrates, Materials Science Engineering: B, 2009, vol. 164, 60-64.

[9] R. M. Batista, E. N. S. Muccillo, Densification and grain growth of 8 YSZ containing NiO”, Ceramics International, 2011, vol. 37, n. 3, 1047-1053.

[10] W. D. Kingery, Introduction to ceramics, 1960, 2 ed., New York, John Wiley.

[11] B. J. Kellet, F. F. Lange, Thermodynamics of densification: I, sintering of simple particle arrays, equilibrium configurations, pore stability, and shrinkage, Journal of the American Ceramic Society, 1989, vol. 72, n. 5, 725-734.

[12] R. Muccillo, M. Kleitz, E. N. S. Muccillo, Flash Grain Welding in Yttria Stabilized Zirconia, Journal of The European Ceramic Society, 2011, vol. 31, n. $8,1517-1521$.

[13] I. W. Chen, X. W. Wang, Sintering dense nanocrystalline ceramics without final-stage grain growth, Nature, 2000, vol. 404, n. 9, 168-171.

[14] M. Okamoto, Y. Akimune, K. Furuya, M. Hatano, M. Yamanaka, M. Uchiyama, Phase transition and electrical conductivity of scandia-stabilized zirconia prepared by spark plasma sintering process, Solid State Ionics, 2005, vol. 176, n. 7-8, 675-680. 
[15] U. A. Tamburini, J. E. Garay, Z. A. Munir, Fast low-temperature consolidation of bulk nanometric ceramic materials, Scripta Materialia, 2006, vol. 54, n. $5,823-828$.

[16] I. Sulima, Consolidation of AISI316L Austenitic Steel - TiB2 Composites by SPS and HP-HT Technology, Sintering Techniques of Materials, In: Sintering Techniques of Materials, 2015, InTech, 125-153.

[17] V. Trombini, E. M. J. A. Pallone, Z. A. Munir, R. Tomasi, Spark plasma sintering (SPS) de nanocompósitos de Al2O3-ZrO2, Cerâmica, 2007, vol. 53, n. $325,62-67$.

[18] K. D. Robles Arellano, L. Bichler, K. Akkiraju, R. Fong, K. Mondal, Densification behavior of Spark Plasma Sintered $\mathrm{La}_{2} \mathrm{O}_{3}$-YSZ ceramics composites, Ceramics International, 2014, vol. 40, n. 1, 715-722.

[19] K. Rajeswari, M. Buchi Suresh, U. S. Hareesh, Y. Srinivasa Rao, Dibakar Das, Roy Johnson, Studies on ionic conductivity of stabilized zirconia ceramics (8YSZ) densified through conventional and non-conventional sintering methodologies, 2011, vol. 37, n. 8, 3557-3564.

[20] K. Rajeswari, M. Buchi Suresh, Dibyendu Chakravarty, Dibakar Das, Roy Johnson, Effect of nano-grain size on the ionic conductivity of spark plasma sintered 8YSZ electrolyte, International Journal of Hydrogen Energy, 2012, vol. 37, n. 1, 511-517.

[21] K. A. Khor, X. J. Chen, S. H. Chan, L. G. Yu, Microstructure-property modifications in plasma sprayed $20 \mathrm{wt}$ \% yttria stabilized zirconia electrolyte by spark plasma sintering (SPS) technique, Materials Science and Engineering A, 2004, vol. 366, n. 1, 120-126.

[22] X. J. Chen, K. A. Khor, S. H. Chan, L. G. Yu, Preparation yttria-stabilized zirconia electrolyte by spark-plasma sintering, 2003, Material Science and Engineering A, vol. 341, n. 1-2, 43-48.

[23] M. A. C. Berton, C. M. Garcia, C. Gusso, M. C. Nascimento, R. Muccillo, Nanotecnologia Aplicada a Geração de Energia Elétrica: Síntese e Caracterização e Testes Operacionais de Eletrólito Sólido para Célula a Combustível de Óxido Sólido, Eletroevolução, 2008, vol. 50, 17-23. 
[24] Z. A. Munir, U. Anselmi-Tamburini, M. Ohiyanagi, The effect of electric field and pressure on the synthesis and consolidation of materials: A review of the spark plasma sintering method, Journal of Materials Science, 2006, vol. 41, n. 3, 763-777.

[25] J. Van Herle, R. Vasquez, Conductivity of Mn and Ni-doped stabilized zirconia electrolyte, Journal of the European Ceramic Society, 2004, vol. 24, n. 6, 1177-1180.

[26] T. S. Zhang, Z. H. Du, S. Li, L. B. Kong, X. C. Song, J. Lu, J. Ma, Transitional metal-doped $8 \mathrm{~mol} \%$ yttria-stabilized zirconia electrolytes, Solid State Ionics, 2009, vol. 180, n. 23-25, 1311-1317.

[27] J. E. Bauerle, Study of electrolyte polarization by a complex admittance method, Journal of Physics and Chemistry of Solids, 1969, vol. 30, n. 12, 2657-2670. 
